\title{
Impacts of Parental Involvement on English Language Learning of Vietnamese Secondary School Students: Understanding Parents' Perceptions
}

\author{
Nhu Quynh Le, Hong Thi Phuong Nguyen \\ Can Tho University, Vietnam
}

\begin{abstract}
This paper reports a descriptive study that examined Vietnamese parents' perceptions of the impacts of their parental involvement on their children's English language learning at secondary school. It draws on data collected as part of a larger project. Data were collected using including a questionnaire and semi-interviews and analysed using descriptive statistics. Findings reveal that parents held positive perceptions of their involvement on their children's English language learning outcome. Implications for practical applications of parental involvement are also presented.
\end{abstract}

Key Words: parental involvement, middle schools, secondary level, parents' perceptions, English language learning.

\section{INTRODUCTION}

Research into parental involvement has addressed its role and positive impact on children's academic performance, especially for English language learning the past few decades. However, there are still many aspects of parental involvement that have not yet been fully explored. Parental involvement has been looked at from the teachers' and administrators' perceptions but has not really been studied through the eyes of parents. For example, Baker, Kessler-Skar, Piotrkowski, and Parker (1999) looked at the type of parental involvement that teacher reported they knew about and the involvement they did not have knowledge of. However, these researches rarely asked the parents about their involvement. Also, Izzo, Weissberg, Kasprow, and Fendrich (1999) cared for parental involvement throughout the time but just judged this involvement with the teachers' perception. Then in 2002, Levine looked at teachers' perceptions of parent involvement and how the parents influence the development of children's literacy skills but she failed to ask the parents about their own involvement. A few studies have been conduct that involves the parents being asked question, but they are few and small. This paper is going to address that problem and investigate to understand parents' perceptions of parental involvement in English language learning, particularly in their secondary school children in the Mekong delta, Vietnam.

The research question that guided the study reported on in this paper was: "What are parents' perceptions of the impacts of parental involvement on children's English language learning at secondary school?"

\section{Literature REVIEW}

\section{A. Definition of Parental Involvement}

The definition of parental involvement has been discussed for many years, therefore there are several definitions of parental involvement. Morgan, Fraser, Dunn and Cairns (1992) explained parental involvement as a complex intercommunication between parents and teachers which facilitates their perception and background knowledge to get involved in children's education tasks. Redding (1992) said that parental involvement is related to parental engagement in learning in home environment or any learning exercise. According to Grolnick and 
DOI: $\underline{10.51386 / 25815946 / i j s m s-v 4 i 4 p 113}$

Volume: 4 Issue: 4

July to August 2021

https://www.ijjsmsjournal.org

Slowiaczek (1994), parental involvement, in general, is a devotion in which all the knowledge that parents have are given to their kids. Sheldon and Epstein (2005) defined parental involvement as a large number of various activities and collaborations among schools, families and communities. A good education is shaped by the coordinated interactions between these factors, in particular, the bond between school and parents (Vural, 2004). So, there is no doubt that a child's success in school relies a great deal on the combined efforts of home and school. Both of them should collaborate with each other for the sake of the academic performance of the child.

\section{B. Types of Parent Involvement}

The differences of types of parent involvement may require parents to be involved in school activities at various degrees and levels. The amount of time that parent involvement requires depends on the sort of parent involvement activities and whether the activity is in school or at home. These types include volunteerism and fundraising. Volunteerism includes active involvement within the classroom and also the elemental operations of the schools. Fundraising is another type of involvement that plenty of oldsters enjoy. Schools promote parents to be involved in fundraising to assist the school in obtaining resources for the advantage children.

Also, home involvement includes assisting children with homework, reading, inquiring some child's school day, and reviewing information sent home by the college. The last common kind of involvement is using outside resources apart from what's offered at the school (Vera et al., 2012). Other styles of parent involvement work better with some parents relying on language barriers, finances, transportation, daycare, and work obligations (Altschul, 2011). Eventually, last factors include race, education, training, school relation, and resources (Malone, 2015; Vera et al., 2012). Parents often provide moral and emotional support to their children, which translates into choosing appropriate schools for his or her children, offering a section to review, and being a model of hard work for them Medina, M., Guzmán, N., \& Wong-Ratcliff, M. (2015).

\section{Parental Involvement and Secondary School Achievement}

Secondary schools have different atmosphere than elementary schools because students have less opportunities for self study than secondary school ones. Therefore, it is easily recognized that parents is a crucial factor of support of adolescents (Branwhite, 2000). Besides, it was said that students recognize their parents as the main source of knowledge available to them (Kandel \& Lesser 1969).

Deplanty et al. (2007) said that teenagers are influenced in positive manner when home and school environment form a strong friendship. What is more, the way of various forms of parental involvement was examined during adolescent improvement periods in some studies (Eccles \& Harold, 1996). Besides, Garcia Coll, Lamberty, Jenkins, McAdoo, Crnic, Wasik and Garcia (1996) emphasized that social position may affect parental involvement experiences (race, socioeconomic status (SES), and adolescents' gender).

Meanwhile, parents provide more space and time for their kids to develop their own autonomy instead of get involved in every process that their adolescents take which cause interruption of their children's autonomy process (Bhargava \& Witherspoon, 2015; Wang et al., 2014). Also, some kinds of parental involvement decrease during adolescence period because parents may think that it may affect their kids' self-learning so they turn to scaffold independence and bolsters youth's decision making skill (Bhargava \& Witherspoon, 2015).

\section{Parental Involvement in English Language Learning}

Although there are not many studies done about parental involvement in foreign language learning, a number of important concerns stand out about the parental involvement in English language learning.

Chi and Rao's (2003) said that teaching English belongs to totally teachers' responsibility. There is no need for parents to take the responsibility in their children's learning activities. This participation role may be a result of traditional views.

On the other hand, Xuesong (2006) revealed that high-class students from urban China were exposed to English language via different methods by their parents, such as motivating towards learning English, introducing English TV programs and monetary support for English learning. Some parents even help students in learning 


\section{DOI: $\underline{10.51386 / 25815946 / i j s m s-v 4 i 4 p 113}$}

Volume: 4 Issue: 4

July to August 2021

https://www.ijsmsjournal.org

English at home although they don't have much knowledge about it. In Hong Kong, for example, parents frequently encourage their kids to learn English by registering extra English classes or hiring tutors (Bray \& Kwok, 2003).

Senechal (2006) conducted an important study about parents' direct teaching to support their children's education and indirect help to boost language and literacy in their longitudinal studies.

According to Lee (2008), in relation to second language learners, these parental factors towards a specific language have an impact on not only their children's attitudes, advantages and behaviors when learning that language but also their learning results.

In the study conducted in 2008, Arias and Morillo-Campbell categorized parental involvement in English language learning into two models based on diversification in parents in ELL and their communities. They said that in non-traditional models of parental involvement in ELL, it offers a mutual understanding between schools and families.

Lastly, Lamb (1976) found that fathers who took care seriously and showed love in their relationships with both daughters and sons promoted their children's development. Kalayc1, G., \& Öz, H. (2018) also found that male and female parents showed no difference in their involvement.

\section{THE STUDY}

In order to investigate parents' perceptions of the impacts of their parental involvement on their children's English language learning at secondary school, amixed-methods design was used in this study. The mixed-methods design which involves quantitative and qualitative approaches can provide an opportunity to gain in-depth understanding of a particular topic under investigation (Creswell, 2014). For the collection of quantitative data, a questionnaire adapted from Mahmoud (2018) was used. It had three sections with a total of 52 five-Likert items. The first section asks for parents' demographic information regarding gender and age. The second section asks for the frequency of parents' direct and indirect involvement in their children's English language learning. The third section seeks parents' perceptions of the impacts of their parental involvement on their children's English language learning results at secondary school. To complement the quantitative data, we conducted semi-structured interviews with six participating parents individually. The interview questions were divided into two clusters: frequency of parental involvement and parents' perceptions of the impacts of parental involvement.

Participants in this study were 146 parents whose children were attending the grades 6-9 at a secondary state school in Ben Tre province in the Mekong Delta, Vietnam. They were selected on the basis of convenience sampling (Fraenkel etal., 2012). Of this sample, 70 participants (47.9\%) were males and 76 participants (52.1\%) were females. About age groups, 1 participant (0.7\%) was 22-30, 35 participants (24\%) were 31-40, 84 participants (57.5\%) were $41-50$, and 26 participants (17.8\%) were 51 and over.

All of the questionnaire items were checked carefully and piloted to ensure the reliability the instrument. Thirty similar parents were randomly chosen to answer the pilot questionnaire. The Cronbach's alpha for the pilot was .95, indicating a high reliability of the questionnaire. Therefore, the questionnaire was used for the actual data collection.

The quantitative data collected from the questionnaire were statistically analyzed using the computer software Statistical Package for the Social Sciences (SPSS) version 20. The interview responses were hand coded, transcribed, and then translated into English. All of the interview transcripts were read and checked carefully and then categorized into themes to answer the above-mentioned research question. 


\section{DOI: $\underline{10.51386 / 25815946 / i j s m s-v 4 i 4 p 113}$}

Volume: 4 Issue: 4

July to August 2021

https://www.ijsmsjournal.org

\section{FINDINGS}

This section presents the findings of the study with regard to parents' perceptions of the impacts of parental involvement on their children's English language learning at a secondary school in Mekong Delta. The findings reveal that there is a moderate rate in the frequency of parental involvement and a variety of activities and parents held positive thoughts towards the impacts of their involvement on their children's English language learning at secondary school.

\section{A. Frequency of Parental Involvement in Their Children's English Learning at Secondary School}

1) Insights into Frequency of Parental Involvement in Their Children's English Language Learning at Secondary School:

Part A of the questionnaire consists of 26 items which presents the frequency of parental involvement in their children's English language learning at Secondary School.

TABLE I

The Mean Score Of The Frequency Of Parental Involvement

\begin{tabular}{llllll}
\hline & N & $\begin{array}{l}\text { Minimu } \\
\text { m }\end{array}$ & $\begin{array}{l}\text { Maxi } \\
\text { mum }\end{array}$ & Mean & $\begin{array}{l}\text { Std. } \\
\text { Deviatio } \\
\mathbf{n}\end{array}$ \\
\hline MeanF & 146 & 1.50 & 5.00 & 2.8317 & .68280 \\
$\begin{array}{l}\text { Valid N } \\
\text { (listwise) }\end{array}$ & 146 & & & & \\
\hline
\end{tabular}

As can be seen from Table I, the total mean score of the overall frequency of parental involvement $(M=2.83, S D=.68)$ was moderately acceptable.

TABLEII

Paired SAMPles Statistics OF MEAn SCORE OF DiReCt INVOLVEMENT AND INDIRECT INVOLVEMENT

\begin{tabular}{llllll} 
& Mean & $\mathbf{N}$ & $\begin{array}{l}\text { Std. } \\
\text { Deviation }\end{array}$ & $\begin{array}{l}\text { Std. } \\
\text { Error } \\
\text { Mean }\end{array}$ \\
\hline & $\begin{array}{l}\text { MeanDir } \\
\text { ect }\end{array}$ & $\begin{array}{l}2.761 \\
9\end{array}$ & 146 & .69424 & .05746 \\
$\begin{array}{l}\text { Pair } \\
1\end{array}$ & $\begin{array}{l}\text { MeanIndi } \\
\text { rect }\end{array}$ & $\begin{array}{l}2.901 \\
5\end{array}$ & 146 & .83339 & .06897 \\
\hline
\end{tabular}

TABLE III

PAIRED SAMPLES TeSt OF MEAN SCORE OF DiRect INVOLVEMENT AND INDIRECT INVOLVEMENT

\begin{tabular}{llllll}
\hline Mean & $\begin{array}{l}\text { Std. } \\
\text { Deviation }\end{array}$ & $\begin{array}{l}\text { Std. } \\
\text { Error } \\
\text { Mean }\end{array}$ & T & Df & $\begin{array}{l}\text { Sig. (2- } \\
\text { Tailed) }\end{array}$ \\
\hline- & .69867 & .05782 & -2.415 & 145 & .017 \\
\hline 13962 & & & & & \\
\hline
\end{tabular}

Table IIand III show that a paired samples T-test was run to assess which type of involvement parents get involved more in their children's English Language Learning of Secondary School: Direct or Indirect involvement. The result indicated that the difference between the two mean scores $(M=2.76, M=2.90)$ is statistically significant $(\mathrm{t}=-2.4, \mathrm{p}=.017)$. So, parents get involved in indirect involvement more than direct involvement. 


\section{DOI: $\underline{10.51386 / 25815946 / i j s m s-v 4 i 4 p 113}$}

Volume: 4 Issue: $4 \quad$ July to August $2021 \quad$ https://www.ijsmsjournal.org

TABLE IV

Group Statistics Of Frequency Of Involvement Of MaLe And Female Parents

\begin{tabular}{llccll} 
& Gender & N & Mean & $\begin{array}{l}\text { Std. } \\
\text { Deviatio } \\
\text { n }\end{array}$ & $\begin{array}{l}\text { Std. } \\
\text { Error } \\
\text { Mean }\end{array}$ \\
\hline Mean & Male & 70 & 2.7824 & .65011 & .07770 \\
Frequency & Female & 76 & 2.8770 & .71286 & .08177 \\
\hline
\end{tabular}

TABLE V

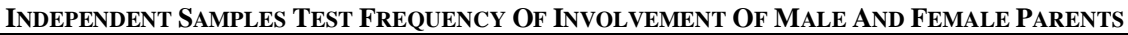

\begin{tabular}{|c|c|c|c|c|c|c|c|}
\hline & $\mathbf{F}$ & Sig. & $\mathbf{T}$ & Df & $\begin{array}{l}\text { Sig.(2- } \\
\text { Tailed) }\end{array}$ & $\begin{array}{l}\text { Mean } \\
\text { Difference }\end{array}$ & $\begin{array}{l}\text { Std. Error } \\
\text { Difference }\end{array}$ \\
\hline $\begin{array}{l}\text { Equal } \\
\text { Variances } \\
\text { Assumed }\end{array}$ & 1.105 & .295 & -836 & 144 & .405 & -.09461 & .11323 \\
\hline $\begin{array}{l}\text { Equal } \\
\text { Variances } \\
\text { Not } \\
\text { Assumed }\end{array}$ & & & -839 & 143.987 & .403 & -.09461 & .11280 \\
\hline
\end{tabular}

As seen in the table IV and V, an independent samples T-test was run to find out if there is a difference in Parental involvement in their children's English Language Learning at Secondary School with regard to male parents and female parents. The mean of male parents' involvement was $2.78(\mathrm{sd}=.65)$, and the mean of female parents' involvement was $2.87(\mathrm{sd}=.71)$. The difference between the involvement of the two groups is not significant (Sig. $=.295>\alpha=0.05$ and Sig. $(2$-tailed $)=.405>\alpha=0.05)$. Therefore, it can be concluded that there is no statistically significant difference between male parents and female parents in their involvement in their children's English Language Learning at Secondary School.

TABLE VI

\begin{tabular}{lllllll}
\multicolumn{6}{c}{ INDEPENDENT SAMPLES T-TEST OF MEAN OF FREQUENCY OF AGE GROUPS } \\
\hline $\begin{array}{l}\text { Age } \\
\text { Group } \\
\text { s }\end{array}$ & $\mathbf{N}$ & Mean & $\begin{array}{l}\text { Std. } \\
\text { Devia } \\
\text { tion }\end{array}$ & $\begin{array}{l}\text { Std. } \\
\text { Erro } \\
\text { r }\end{array}$ & $\begin{array}{l}\text { Minim } \\
\text { um }\end{array}$ & $\begin{array}{l}\text { Maxim } \\
\text { um }\end{array}$ \\
\hline $22-30$ & 1 & 2.653 &. &. & 2.65 & 2.65 \\
$31-40$ & 35 & 8 & .6941 & .1173 & 1.50 & 5.00 \\
$41-50$ & 84 & 2.775 & 6 & 3 & 1.65 & 4.58 \\
Over & 26 & 8 & .6814 & .0743 & 1.88 & 4.77 \\
50 & 14 & 1 & .6965 & .1366 & 1.50 & 5.00 \\
Total & 6 & 2.954 & 7 & 1 & & \\
& & 1 & .6828 & .0565 & & \\
& & 2.831 & 0 & 1 & & \\
& & 7 & & & & \\
\hline
\end{tabular}




\section{DOI: $\underline{10.51386 / 25815946 / \mathrm{ijsms}-\mathrm{v} 4 \mathrm{i} 4 \mathrm{p} 113}$}

Volume: 4 Issue: 4

July to August 2021

https://www.ijsmsjournal.org

TABLE VII

TEST OF HOMOGENEITY OF VARIANCES

\begin{tabular}{|c|c|c|c|c|c|}
\hline \multicolumn{2}{|l|}{ Levene Statistic } & Df1 & Df2 & \multicolumn{2}{|c|}{ Sig. } \\
\hline $.093^{\mathrm{a}}$ & & 2 & 142 & \multicolumn{2}{|c|}{.911} \\
\hline \multicolumn{6}{|c|}{ TABLE VIII } \\
\hline ANOVA OF FRE & EQUENCY OF I & ARENT & JVOLVEME & F AGE & OUPS \\
\hline & $\begin{array}{l}\text { Sum Of } \\
\text { Squares }\end{array}$ & Df & $\begin{array}{l}\text { Mean } \\
\text { Square }\end{array}$ & $\mathbf{F}$ & Sig. \\
\hline $\begin{array}{l}\text { Between } \\
\text { Groups }\end{array}$ & .544 & 3 & .181 & .384 & .765 \\
\hline $\begin{array}{l}\text { Within } \\
\text { Groups }\end{array}$ & 67.057 & 142 & .472 & & \\
\hline Total & 67.601 & 145 & & & \\
\hline
\end{tabular}

Table VI, VII and VIII show the results of one-way analysis of variance (ANOVA) to see if parental involvement in children's English language learning had some impacts with regard to age factor ranging from 22 $30,31-40,41-50$ to over 50 . The mean of parents aged 22-30 was 2.65, the mean of parents aged 31-40 was 2.77, the mean of parents aged 41-50 was 2.81 and the mean of parents aged over 50 was 2.95. The difference between the involvement of four age groups is not significant (Sig. $=.911>\alpha=0.05$ and Sig. F $($ ANOVA) $=.765>\alpha=$ 0.05). In other words, there is no statistically significant difference in parental involvement in children's English language learning at secondary school with regard to age factor ranging from 22-30, 31-40, 41-50 to over 50. This indicates that parents of all ages tend to be equally involved in their children's learning of the English language.

\section{2) Insights into Frequency of Direct Involvement of Parents in their Children's English Language Learning at Secondary School:}

Analysis of the interview data reveals that the six participating parents got involved directly in their children's English learning by doing a number of activities.

\section{Encouraging children to do their homework}

Among the six parents, two said that they assisted their children while they were doing their homework. To be specific, the first parent said he sometimes explained the difficult tasks to his child. Moreover, the second parent even said her son did his homework with her.

If my son doesn't understand the lesson, I will explain it again to him based on what I know. But just sometimes, I don't have much time. (P1, line 6)

I also do homework with my son, the one at school or from online course. (P6, line 129)

About doing homework, I always encourage and get involved in doing homework with him. For example, I ask him to teach me a new word to make him engaged in. (P6, line 131)

While other 2 parents argued that they always try to make their children do the homework on their own.

I always encourage my child to do homework himself at home. (P3, line 59)

Sometimes, I have to follow him while doing my own work. (P3, line 61)

I ask my son to do extra English exercises to practice more what he learnt at school. (P4, line 82)

About doing extra exercise, I encourage him to spend an hour doing it everyday. (P4, line 87) 


\section{DOI: $\underline{10.51386 / 25815946 / \mathrm{ijsms}-\mathrm{v} 4 \mathrm{i} 4 \mathrm{p} 113}$}

Volume: 4 Issue: 4

July to August 2021

https://www.ijsmsjournal.org

Finally, the last two parents attributed the children's success to their teacher and stated that their role cannot go beyond reminding their children to do homework.

Besides if she doesn't understand the lesson, I always ask her to contact her English teacher for help.

She usually asks her teacher when she has any problems. (P5, line 113)

\section{Encouraging children to watch English programs on TV or Youtube}

All participating parents see its advantages in improving listening skill and enhance vocabulary range and knowledge. However, four parents encourage their children to do so more frequently than the rest.

It's helpful so I usually ask him to do so. (P1, line 10)

Whenever she finishes her homework, I always encourage her to do so. It's a good way to learn and to relax. $(P 2$, line 43)

After he finishes his homework, I let him watch English programs for 30 minutes everynight. (P4, line 89)

I let her watch TV 3 times per week, and about an hour per day (P5, line 111)

While only two parents were afraid that their sons would be addicted to it, so they only permitted them to do so on weekends.

Yes, but not much. So, I only let him watch at weekend under my observation. (P3, line 67)

About watching TV, I'm afraid he will be addicted to it. So I only let him do so twice a week. (P6, line 133)

\section{Registering extra English classes for their children}

Five out of 6 participants showed a similar thought and frequency. Although extra class only accounts for only 3 sessions per week, it still shows a positive trend that they did care about building up and expanding knowledge for their children.

Yes, studying at school is good to build up basic knowledge. Moreover, taking extra English class helps him recall in-class knowledge and have more time to practice more. (P1, line 12)

Three times a week with his friends (P1, line 18)

I let her study extra class afterschool 3 times a week. (P2, line 35)

I register extra English class three times 1 week. I think learning at school is not enough for him. Learning extra class provides him with more exercises and the teacher shows method of doing test which is good for him. (P3, line 63)

The rest of time she has to take extra English class. (P5, line 111)

It takes 3 time per week on Tuesday, Thursday and Saturday. (P5, line 115)

About online course, I choose 3 times a week, Monday, Wednesday and Friday (P6, line 132)

There is only one parent showed his dedicated involvement by hiring a tutor to improve his child's speaking skill and it also comprised of 3 sessions.

...twice a week with the tutor. (P1, line 19)

\section{Praising children during their learning process}

Two parents always did so. The second parent indicated that she tried to enhance children's motivation by always praising and giving her daughter advice. 


\section{DOI: $\underline{10.51386 / 25815946 / \mathrm{ijsms}-\mathrm{v} 4 \mathrm{i} 4 \mathrm{p} 113}$}

Volume: 4 Issue: 4

July to August 2021

https://www.ijsmsjournal.org

Although I can't help her much in her learning, I focus on her mental health, so I always praise and give her advice in taking care of her health. If she gets a bad score, I will support and motivate her to try next time. $(P 2$, line 41)

I always praise and give her advice in taking care of her health. If she gets a bad score, I will support and motivate her to try next time. (P2, line 41)

The other parent showed her concern by encouraging and reminding her son to try harder every day.

I also encourage and remind him every day to try harder. (P3, line 65)

\section{Creating a friendly environment at home}

Several parents mentioned implementing this activity for their children because they want their children feel comfortable to learn English at home after school.

Besides, I always create a comfortable learning environment at home which she can learn English better. $(P 2$, line 41)

I always encourage my child to do homework himself at home by talking and praising to make him motivated in his English learning. (P3, line 59)

In addition to this, I always want him to learn comfortably, so creating a friendly environment at home is essential. (P6, line 131)

\section{Encouraging children to read English books}

Only one parent said that she encouraged her son to read English books more afterschool.

I encourage him to read English books because it helps him to enhance his vocabulary. (P4, line 84)

About reading books, I ask him to read them 3-4 times per week. (P1, line 88)

3) Insights into Frequency of Indirect Involvement of Parents in their Children's English Language Learning at Secondary School:

Analysis from the interview data reveals that the three participating parents got involved indirectly in their children's English learning by doing a lot of activities.

\section{Supporting indirectly children in learning English}

Only one parent indicated that his child could learn the language without his involvement. Specifically, he mentioned his son learnt with a group of friends to share opinions or ask for advice with difficult exercises on regular basis.

He has 2 close friends who take extra English class with. They usually make video call to share or asking for advice with difficult exercises. I see it really motivates him to learn more (P1, line 8)

He does it more regularly, about 4-5 times a week. Because I want him to be good at English, so he spend more time on learning it. (P1, line 16)

\section{Keeping in touch with the English teacher} school.

All of the participants said they contacted the English to know about their children learning process at

I always contact the teacher who directly teaches my son at school to know if he could learn well at school. $(P 1$, line 24)

I ask my daughter's English teacher how she learns (P2, line 45)

I sometimes ask the teacher about my son's learning process. (P3, line 69) 


\section{DOI: $\underline{10.51386 / 25815946 / \mathrm{ijsms}-\mathrm{v} 4 \mathrm{i} 4 \mathrm{p} 113}$}

Volume: 4 Issue: 4

July to August 2021

https://www.ijsmsjournal.org

I always spend time contacting English teacher sometimes to know the learning outcomes so that I can support him. (P4, line 93)

I really concern about my daughter learning process, so twice a week, I keep in touch with her English teacher. (P5, line 107)

I usually keep in touch with my son's English teacher at school and center to support more. (P6, line 137)

\section{Keeping in touch with other parents}

Four out of 6 parents said they wanted to know what they learn at school, extra class and support them more at home and even share their own way to help their own children. However, they did it not very often due to their busy schedule at work.

Moreover, I keep in touch with parents of my son's close friends to know what they learn at school, extra class and support them more at home (P1, line 25)

I have some friends whom children are studying with my child. We keep in touch to share our own ways to help our children, but not regularly because we are so busy. We let them learn by themselves more often. (P3, line 70)

Not regularly because we are so busy. (P3, line 70)

I also contact other parents at school to find good methods to help my son (P4, line 94)

We share and give advice to support our children 1-2 times a week. (P5, line 119)

\section{B. Parents' Perceptions of the Impacts of their Involvement on their Children's English Learning at Secondary} School.

1) Insights into Parents' Perceptions of the Impacts of Parental Involvement on their Children's English Language Learning at Secondary School:

The second part of the questionnaire consists of 26 items which presents the perceptions of the impacts of parental involvement in their children's English language learning at Secondary School.

TABLE IX

The Mean Score Of The Overall Perceptions Of The Impacts Of Parental Involvement

\begin{tabular}{|c|c|c|c|c|c|}
\hline & $\mathbf{N}$ & $\begin{array}{l}\text { Mini } \\
\text { mum }\end{array}$ & $\begin{array}{l}\text { Maxi } \\
\text { mum }\end{array}$ & Mean & $\begin{array}{l}\text { Std. } \\
\text { Deviation }\end{array}$ \\
\hline MeanImpact & 146 & 1.23 & 4.92 & $\begin{array}{l}2.602 \\
7\end{array}$ & .72668 \\
\hline $\begin{array}{ll}\text { Valid } & \mathrm{N} \\
\text { (listwise) } & \end{array}$ & 146 & & & & \\
\hline
\end{tabular}

As can be seen from Table 4.9, the total mean score of the perceptions of the impacts of parental involvement $(M=2.60, S D=.72)$ was moderately acceptable.

TABLE X

Paired Samples Statistics Of Parents' Perceptions Of The ImPacts

\begin{tabular}{llllll}
\hline & Mean & N & Std. Deviation & Std. Mean \\
\hline \multirow{2}{*}{ Pair 1 } & MeanPerceptionDirect & 2.5854 & 146 & .72506 & .06001 \\
& MeanPerceptionIndirect & 2.6201 & 146 & .81168 & .06718 \\
\hline
\end{tabular}




\section{DOI: $\underline{10.51386 / 25815946 / i j s m s-v 4 i 4 p 113}$}

Volume: 4 Issue: $4 \quad$ July to August $2021 \quad \underline{\text { https://www.ijjsmsjournal.org }}$

TABLE XI

Paired Samples Correlations Of Parents' Perceptions Of The IMPaCts

\begin{tabular}{lllll}
\hline & & $\mathrm{N}$ & $\begin{array}{l}\text { Correlati } \\
\text { on }\end{array}$ & Sig. \\
\hline $\begin{array}{l}\text { Pair } \\
1\end{array}$ & $\begin{array}{l}\text { Mean Perception Direct } \\
\text { Mean Perception Indirect }\end{array}$ & 146 & .788 & .000 \\
\hline
\end{tabular}

TABLE XII

Paired Samples Test Of Parents' Perceptions Of The Impacts

\begin{tabular}{lllllll}
\hline & $\begin{array}{l}\text { Mea } \\
\text { n }\end{array}$ & $\begin{array}{l}\text { Std. } \\
\text { Devia } \\
\text { tion }\end{array}$ & $\begin{array}{l}\text { Std. } \\
\text { Error } \\
\text { Mean }\end{array}$ & t & df & $\begin{array}{l}\text { Sig.(2- } \\
\text { tailed) }\end{array}$ \\
\hline $\begin{array}{l}\text { Mean Perception Direct } \\
\text { Mean Perception Indirect }\end{array}$ & - & .5068 & .04194 & - & 14 & .408 \\
& .034 & 1 & & .8 & 5 & \\
& 77 & & & 29 & & \\
\hline
\end{tabular}

A paired sample T-test was run to assess which type of involvement parents perceive its impacts in their children's English Language Learning of Secondary School: Direct or Indirect involvement. The result indicated that the difference between the two mean scores $(\mathrm{M}=2.58, \mathrm{M}=2.62)$ is not statistically significant $(\mathrm{t}=-.82, \mathrm{p}=.40)$. So, parents' perception of the impacts of direct involvement is the same as indirect involvement. (Table X, XI and XII)

TABLE XIII

Group Statistics Of Parents' Perceptions Of Their Involvement With Regard To Gender Factor

\begin{tabular}{llllll} 
& $\begin{array}{l}\text { Gend } \\
\text { er }\end{array}$ & $\mathbf{N}$ & Mean & $\begin{array}{l}\text { Std. } \\
\text { Deviatio } \\
\mathbf{n}\end{array}$ & $\begin{array}{l}\text { Std. } \\
\text { Error } \\
\text { Mean }\end{array}$ \\
\hline & Male & 70 & $\begin{array}{l}2.516 \\
5\end{array}$ & .72343 & .08647 \\
$\begin{array}{l}\text { MeanIm } \\
\text { pact }\end{array}$ & $\begin{array}{llll}\text { Fema } \\
\text { le }\end{array}$ & 76 & $\begin{array}{l}2.682 \\
2\end{array}$ & .72532 & .08320 \\
\hline
\end{tabular}

TABLE XIV

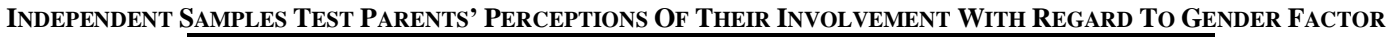

\begin{tabular}{|c|c|c|c|c|c|c|c|}
\hline & $\mathbf{F}$ & $\begin{array}{l}\mathrm{Si} \\
\text { g. }\end{array}$ & $\mathbf{t}$ & df & $\begin{array}{l}\text { Sig. } \\
(2- \\
\text { tail } \\
\text { ed) }\end{array}$ & $\begin{array}{l}\text { Mean } \\
\text { Differ } \\
\text { ence }\end{array}$ & $\begin{array}{l}\text { Std. } \\
\text { Error } \\
\text { Differen } \\
\text { ce }\end{array}$ \\
\hline $\begin{array}{l}\text { Equal } \\
\text { variances } \\
\text { assumed }\end{array}$ & $\begin{array}{l}.1 \\
3 \\
1\end{array}$ & $\begin{array}{l}.7 \\
18\end{array}$ & $\begin{array}{l}- \\
1.3 \\
81\end{array}$ & 144 & $\begin{array}{l}.16 \\
9\end{array}$ & $\begin{array}{l}- \\
.16570\end{array}$ & .12001 \\
\hline $\begin{array}{l}\text { Equal } \\
\text { variances } \\
\text { not assumed }\end{array}$ & & & $\begin{array}{l}- \\
1.3 \\
81\end{array}$ & $\begin{array}{l}143 . \\
079\end{array}$ & $\begin{array}{l}.16 \\
9\end{array}$ & $\begin{array}{l}- \\
.16570\end{array}$ & 11999 \\
\hline
\end{tabular}




\section{DOI: $\underline{10.51386 / 25815946 / i j s m s-v 4 i 4 p 113}$}

Volume: 4 Issue: 4

July to August 2021

https://www.ijjsmsjournal.org

As can be seen from Table XIIand XIV, an independent samples T-test was run to find out if there is a difference in parents' perceptions of their involvement in their children's English Language Learning at Secondary School with regard to gender factor. The mean of male parents' perceptions was $2.51(\mathrm{sd}=.72)$, and the mean of female parents' perceptions was $2.68(\mathrm{sd}=.72)$. The difference between the perceptions of the two groups is not significant (Sig. $=.71>\alpha=0.05$ and Sig. (2-tailed) $=.169>\alpha=0.05$ ). Therefore, it can be concluded that there is no statistically significant difference between male and female in parents' perceptions of their involvement in their children's English Language Learning at Secondary School.

\section{TABLE XV}

The Mean Scores Of Parents' Perceptions Of The ImPaCts With Regard To Age Factor

\begin{tabular}{lllllll}
$\begin{array}{l}\text { Age } \\
\text { groups }\end{array}$ & $\mathbf{N}$ & Mean & $\begin{array}{l}\text { Std. } \\
\text { Devia } \\
\text { tion }\end{array}$ & $\begin{array}{l}\text { Std. } \\
\text { Error }\end{array}$ & $\begin{array}{l}\text { Mini } \\
\text { mum }\end{array}$ & $\begin{array}{l}\text { Maxi } \\
\text { mum }\end{array}$ \\
\hline $22-30$ & 1 & 2.192 &. &. & 2.19 & 2.19 \\
& & 3 & & & & \\
$31-40$ & 35 & 2.648 & .6350 & .10734 & 1.46 & 4.81 \\
& & 4 & 2 & & & \\
$41-50$ & 84 & 2.544 & .7623 & .08318 & 1.23 & 4.65 \\
& & 9 & 1 & & & \\
Over & 26 & 2.744 & .7370 & .14456 & 1.81 & 4.92 \\
50 & & 1 & 9 & & & \\
Total & 14 & 2.602 & .7266 & .06014 & 1.23 & 4.92 \\
& 6 & 7 & 8 & & & \\
\hline
\end{tabular}

TABLE XVI

Test Of HoMogeneity Of Variances Of Parents' Perceptions The IMPacts

\begin{tabular}{llll} 
Levene Statistic & df1 & df2 & Sig. \\
\hline $1.307^{\mathrm{a}}$ & 2 & 142 & .274 \\
\hline
\end{tabular}

Table XVII

ANOVA OF PARENTS' PERCEPTIONS OF THE IMPACTS

\begin{tabular}{lccccc}
\hline & $\begin{array}{l}\text { Sum of } \\
\text { Squares }\end{array}$ & df & $\begin{array}{l}\text { Mean } \\
\text { Square }\end{array}$ & F & Sig. \\
\hline $\begin{array}{l}\text { Between } \\
\text { Groups }\end{array}$ & 1.042 & 3 & .347 & .653 & .582 \\
\hline $\begin{array}{l}\text { Within } \\
\text { Groups }\end{array}$ & 75.526 & 142 & .532 & & \\
\hline Total & 76.568 & 145 & & & \\
\hline
\end{tabular}

As seen in Table XV, XVI and XVII, one-way analysis of variance (ANOVA) was also conducted to see if parents' perceptions of the impacts of parental involvement in children's English language learning with regard to age factor ranging from 22-30, 31-40, 41-50 to over 50. The mean of parents aged 22-30 was 2.19, the mean of parents aged 31-40 was 2.64, the mean of parents aged 41-50 was 2.54 and the mean of parents aged over 50 was 


\section{DOI: $\underline{10.51386 / 25815946 / \mathrm{ijsms}-\mathrm{v} 4 \mathrm{i} 4 \mathrm{p} 113}$}

Volume: 4 Issue: 4

July to August 2021

https://www.ijsmsjournal.org

2.74. The difference between the involvement of 4 age groups is not significant (Sig. $=.274>\alpha=0.05$ and $\mathrm{Sig}$. $\mathrm{F}$ $($ ANOVA $)=.582>\alpha=0.05)$. Therefore, it can be concluded that there is no statistically significant difference in parents' perceptions of the impacts of parental involvement in children's English language learning at Secondary school with regard to age factor ranging from 22-30, 31-40, 41-50 to over 50.

2) Insights into Parents' Perceptions of the Impacts of Direct Involvement on their Children's English Language Learning at Secondary School:

\section{Encouraging children to do their homework}

Two parents argued that their involvement did not create a significant difference on their children's English development. Among them, one parent thought it was somewhat effective and the other thought it was not so effective.

I don't think it helps him because most of the time he just does it himself or discusses with his friends. (P1, line 14)

I see after asking teacher, she can do her homework well. (P2, line 37)

The scores have not improved much (P3, line 69)

And his grammar is better thanks to doing extra exercise. (P4, line 91)

I see she shows her interest and learns better than before (P5, line 117)

One parent reflected her desire to do exercise with her daughter. She stated that they learnt new words together for contributing to her daughter's vocabulary.

For example, by doing homework with me, he can learn vocabulary better. (P6, line 135)

\section{Encouraging children to watch English programs on TV or YouTube}

Parents believed that they had an influence on letting their children watch TV. Five participating parents thought watching English programs was very effective.

It's helpful so I usually ask him to do so. (P1, line 10)

I think learning from English programs is also effective. (P2, line 45)

Watching English programs makes her interesting. (P3, line 47)

His learning outcome has been improved so much especially listening and speaking skills through reading books and watching TV (P4, line 91)

I see she shows her interest and learns better than before (P5, line 117)

Only one parent thought it was somewhat effective. She also mentioned the importance of the language exposure for the development of English.

I think my son can learn with many different accents, not only one at school. But, it is somewhat effective. (P6, line 135)

Two of those parents said it was also a relaxation, but only one thought it was not effective.

It's a good way to learn and to relax. (P2, line 43)

But I think it's just for fun. (P3, line 67)

\section{Registering extra English class for their children}

All of the parents show a positive thought of letting their children learn extra English class. They all thought it was very effective. 


\section{DOI: $\underline{10.51386 / 25815946 / \mathrm{ijsms}-\mathrm{v} 4 \mathrm{i} 4 \mathrm{p} 113}$}

Volume: 4 Issue: 4

July to August 2021

https://www.ijsmsjournal.org

His English teacher and tutor said he got better scores (P1, line 22)

As I see, it is effective because she learns with the teacher who teaches her in class (P2, line 35)

I ask my daughter's English teacher how she learns. Her response is she learns quite well. She also gets better score recently. (P2, line 45)

Learning extra class provides him with more exercises and the teacher shows method of doing test which is good for him. (P3, line 63)

I see she shows her interest and learns better than before (P5, line 117)

Besides, by learning online, his speaking reaction is quite good, so I think it is effective. (P6, line 135)

\section{Praising children during their learning process}

Caring about mental health is also a good method to motivate children to learn better. Two parents thought it was somewhat effective.

It somewhat makes her motivated. (P2, line 41)

Although, he followed, maybe he doesn't study hard enough. So I think it's somewhat effective. (P3, line 65)

In terms of creating a friendly environment at home

Three out of six parents who mentioned this activity thought it was effective to help motivate their children try hard and feel comfortable when learning English at home.

Also, when she learns in a comfortable atmosphere at home, she feel interested. (P2, line 47)

So so. Although he learns extra class, follows my requirement and feels comfortable to learn at home, his score has not improved yet. (P3, line 65)

For example, by doing homework with me in a friendly environment, he can learn vocabulary better. (P6, line 135)

\section{Creating a friendly environment at home}

Several parents perceived by creating comfortable learn in environment at home, their children can learn English comfortably and are more motivated.

... which she can learn English better. (P2, line 41)

... praising to make him motivated in his English learning. (P3, line 59)

... I always want him to learn comfortably, so creating a friendly environment at home is essential. (P6, line 131)

\section{Encouraging children reading English books}

Only one parent said by letting children read books in English, their vocabulary, listening and speaking skills are enhanced.

It helps him to enhance his vocabulary. (P4, line 84)

His learning outcome has been improved so much especially listening and speaking skills through reading books. (P4, line 91)

\section{3) Insights into Parents' Perceptions of the Impacts of Indirect Involvement in their Children's English Language Learning at Secondary School:}

Analysis from the interview data reveals that the six participating parents showed their perceptions towards their indirect involvement in their children's English learning by doing a lot of activities. 


\section{DOI: $\underline{10.51386 / 25815946 / \text { ijsms-v4i4p113 }}$}

Volume: 4 Issue: 4

July to August 2021

https://www.ijjsmsjournal.org

\section{Encouraging indirectly children in learning English}

The only parent thought it was very effective in promoting his son's speaking skill.

He shows interest in learning it by actively interacting more with his friends to speak English, (P1, line 21)

\section{Keeping in touch with the English teacher}

One parents thought it was quite effective to ask about his child's learning process from the English teacher.

It's quite effective. (P1, line 24)

One parent said the partnership with teacher will support and improve the education process.

I find it quite effective because two sides which are family and teacher can support more for the child. (P2, line 51)

In contrast, four parents showed teacher's guidance and feedback are effective for them to help know the learning process and remind them to try.

Yes, I know more about his learning process at school and remind him to practice more at home. (P3, line 72)

I always spend time contacting English teacher sometimes to know the learning outcomes so that I can support him. (P4, line 93)

I really concern about my daughter learning process, so twice a week, I keep in touch with her English teacher. I always observe my daughter's learning at home and listen to the teacher's feedback at school to get the precise information. (P5, line 107)

So I think listening from teacher's feedback is very effective. (P6, line 138)

\section{Keeping in touch with other parents}

Two parents thought this involvement was somewhat effective because they just shared or followed their children's learning process when needed. The rest of time, their children discussed or learnt with teacher or by themselves as they said before.

It's also somewhat effective because we just follow and remind them when needed. (P1, line 25)

We let them learn by themselves more often. (P3, line 70)

One parent thought it was effective because she could update information and suitable method for her son. I also contact other parents at school to find good methods to help my son. Besides, I also join in Parent Association to update information and suitable methods. (P4, line 95)

One parent said she didn't have time to keep in touch with other parents.

And I don't have time to contact other parents because I am busy at work. (P6, line 138)

\section{Discussion}

The results of the current study indicates that in general Vietnamese parents held positive thoughts about the impacts of their parental involvement on their children's English language learning at secondary school. However, they felt that although they organized quite a number of activities to get involved in their children's learning of English, their involvement was just at a moderate level and that the impact was also just at a moderate level. Their children's English was still not very good. These findings are quite opposite with the ones in Dubois et al, 1994, who asserted that home-based parental involvement clearly has positive effects on students' success.

However, findings from the interview indicate that the parents have a positive attitude toward their participation in the learning activities of their children. This argument can be explained with Erdener and 
DOI: $\underline{10.51386 / 25815946 / i j s m s-v 4 i 4 p 113}$

Volume: 4 Issue: 4

July to August 2021

https://www.ijjsmsjournal.org

Knoeppel's (2018) result revealing that parents are in the opinion that they accept parents' positive influence on children's achievement although education is school's job even though. These findings verify this argument.

When it comes to the relationship between parents' demographic characteristics and their perceptions about parental involvement, the results suggest no statistically significant difference in terms of gender factor. This finding is consistent with what Kalaycı, G., \& Öz, H. (2018) found. In this study, male and female parents made no difference in their perceptions of the impacts.

Findings from the interview reveal that, we can see several parents provide emotional support rather than being directly involved with their children's studies. This fact aligns with the data provided by Medina, Guzmán \& Wong-Ratcliff (2015) who affirmed that parents of Latin American background tend to provide some form of moral and emotional support, be it by helping them with their assignments, finding an appropriate school for them or simply by being a good role model to them, and how this behavior from Latino parents is based on cultural practices and beliefs. Found that

The second finding from the interview is that some of them highlighted their inclination to understand their children's world, provide a welcoming and motivating home environment for them and spend time with the children, talking and listening to them in patience and love. This finding is in agreement with not only Mahmoud's (2018) result but also Şad and Gürbüztürk's (2013) finding, suggesting that parent often provide a reinforcing environment for their children at home so as to assist their learning.

Besides, parent-teacher relation is very important for a successful child. It can keep both of them aware of what is going on inside and outside schools. The results of the interview with regard to parents' relation with teachers support the above assumption. Nearly all parents' response is to construct partnership with the teachers since it reinforces the students' achievement and promotes the quality of education. The findings of the interview regarding parents-teachers partnership indicate that they frequently keep in touch with teachers, so there is a high level of information exchange about the child's learning outcome and suitable methods between them, which is in consistence with findings of the previous research (Mahmoud, 2018). However, this finding is opposite to what Chi and Rao's (2003) said. In their study, parents agreed that teaching English belongs to totally teachers' responsibility. There is no need for parents to take the responsibility in their children's learning activities.

\section{CONCLUSIONS}

The major findings from this present study provide insights into parents perceptions about the impacts of their involvement on their children's English language learning at secondary school. Those beliefs lay the groundwork for the involvement in actual practices. In light of those findings, some pedagogical implications are given.

First, it is for parents and teachers. As parents mentioned earlier in the findings, parents agreed keeping in touch with teacher has an impact on helping them know their children educational outcomes and support when needed. Thus, the most important implication is to maintain short meetings and discussions as usual. It is especially important for both of them to interact and understand each other to support children in learning English. These meetings or discussions can held online or in real life depending on their schedules and convenience.

Also, it is important to keep parents well aware of opportunities to be involved and of the happenings in the school and classroom. This research seems to say that although not all parents mentioned visiting schools, they may still be active and interested in their child's education. Also, the only relationship with schools is to contact the English teacher to update their children's academic process. Therefore, part of the job of educators is to make parents aware of what is occurring at the school and any/all opportunities to be involved such as attending training, seminars and workshops about how to work in a parallel line with teachers and to consolidate and further practice what the teacher had already started in the classroom. Parents should be reminded constantly through notes, phone calls, and daily conversations that they are needed and wanted in the classroom and school (if they are truly wanted) and what involvement opportunities there are in the school and classroom.

Lastly, findings from the present study show that although parents had a variety of involvement ranging from direct to indirect to encourage their children to learn English. However, these activities are still around their 


\section{DOI: $\underline{10.51386 / 25815946 / \mathrm{ijsms}-\mathrm{v} 4 \mathrm{i} 4 \mathrm{p} 113}$}

Volume: 4 Issue: 4

July to August 2021

https://www.ijsmsjournal.org

house. For example, they encourage their children to watch TV, to read English books which are indoor activities. Therefore, parents should be required to add more activities related to outdoor ones. For example, they can encourage students to join in speaking English club, or take them to some public places to use the language they learn to make a conversation with foreigners, or even make field trips to places where the children can speak English with their friends confidently. However, due to parents' hectic schedule at work, these activities above can be done 1-2 times per year, which could bring huge benefits to children in learning English.

\section{About the Authors}

Nhu Quynh Le is a teacher of English at a foreign language center in Can Tho, Vietnam. She completed a bachelor's degree of English in Education in 2018. She is currently an MA student at Can Tho University. Her research interests include parental involvement and its impacts on students' English learning. She is also keen on strategies for parents and teachers to support English language learning of EFL students.

Hong Thi Phuong Nguyen, has been an English teacher at Can Tho University since 1995. In 2006, she graduated from the US master's program at the Massachusetts University, Boston, USA under the Fubright scholarship program granted by the US Government. Her master's thesis is called American Multiculturalism: Contact and Conflict between Ethnic Groups (A Curriculum Project). In 2013, she graduated from the PhD program in Applied Linguistics and TEFL at the Groningen University, Netherlands, under a TRIG scholarship granted by the Vietnamese Government. Her doctoral thesis is called A Dynamic Usage-based Approach to Second Language Teaching. Her research interests include foreign language teaching and learning methods and emotional factors affecting foreign language learning.

\section{REFERENCES}

[1] Altschul, I. (2011). Parental involvement and the academic achievement of Mexican American youths: What kinds of involvement in youths' education matter most? Social Work Research, 35(3), 159-170.

[2] Arias, M. B., \& Morillo-Campbell, M. (2008). Promoting ELL parental involvement: challenges in contested times. Retrieved January 18, 2017, from http://files.eric.ed.gov/fulltext/ED506652.pdf

[3] Baker, A. J. L., Kessler-Skar, S., Piotrkowski, C. S., \& Parker, F. L. (1999). Alongitudinal assessment of teacher perceptions with learning and behaviorproblems in the schools. Preventing School Failure, 48, 367- 379.

[4] Bhargava, S., \& Witherspoon, D. P. (2015). Parental involvement across middle and highschool: Exploring contributions of individual and neighborhood characteristics. Journal of Youth and Adolescence, 44(9), 1702-1719.

[5] Bray, M., \& Kowk, P. (2003). Demand for private supplementary tutoring: Conceptual considerations, and socio-economic patterns in Hong Kong. Economics of Education Review, 22(6), 611-620.

[6] Chi, J., \& Rao N. (2003). Parental beliefs about school learning and children's educational attainment: Evidence from rural China. Ethos, $31(3), 330-356$.

[7] Creswell, J. W. (2014). Research design: Qualitative, quantitative, and mixed methods approaches (4nd Ed.). Thousand Oaks, California: SAGE Publications.

[8] Deplanty, J., Coulter-Kern, R., \& Duchane, K. (2007). Perceptions of parent involvement in academic achievement. The Journal of Educational Research, 100(61), 361-368.

[9] Eccles, J. S., \& Harold, R. D. (1996). Family involvement in children's and adolescents' schooling. Family-School Links: How Do They Affect Educational Outcomes, 3-34.

[10] Garcia Coll, C., Lamberty, G., Jenkins, R., McAdoo, H. P., Crnic, K., Wasik, B. H., \& Garcı'a, H. V. (1996). An integrative model for the study of developmental competencies in minority children. Child Development, 67(5), 1891-1914. doi:10.1111/j.1467-8624.1996.tb01834.x.

[11] Grolnick, W. S., \& Slowiaczek, M. L. (1994). Parents' involvement in children's schooling: A multidimensional conceptualization and motivational model. Child Development, 65(1), 237-252. 


\section{DOI: $\underline{10.51386 / 25815946 / \text { ijsms-v4i4p113 }}$}

Volume: 4 Issue: 4
July to August 2021 https://www.ijjsmsjournal.org

[12] Izzo, C. V., Weissberg, R. P., Kasprow, W. J., \& Fendrich, M. (1999). A longitudinalassessment of teacher perceptions of parent involvement in children's educationand school performance. American Journal of Community Psychology, 27,817-839.

[13] Kandel, D. B., \& Lesser, G. S. (1969). Parental and peer influences on educational plans of adolescents. American Sociological Review, 213-223.

[14] Lamb, M.E. (1976). The Role of the Father in Child Development. New York: A WileyInterscience Publication.

[15] Lee, Y.C. (2008). Parental involvement and support for Taiwanese children's English language and literacy learning. Master thesis, Boston College, Boston, USA.

[16] Levine, L. A. (2002). Teacher's perceptions of parental involvement: How it effects ourchildren's development in literacy. (Report No. PS-030-410) (ERIC Document Reproduction service No. ED465438).

[17] Mahmoud, S. S. (2018). Saudi parents' perceptions of the kind of help they offer to their primary school kids. English Language Teaching, 11(3), 102-112. https://doi.org/10.5539/elt.v11n3p102

[18] Malone, D. (2015). Culture: A potential challenge for parental involvement in schools. Delta Kappa Gamma Bulletin: International Journal of Professional Educators 82(1), 14-18.

[19] Medina, M., Guzmán, N., \& Wong-Ratcliff, M. (2015). Latino parental involvement: Myths, perceptions and inhibiting factors. Journal of Case Studies in Education, 7, 1-15.

[20] Morgan, V., Fraser, G., Dunn, S., \& Cairns, E. (1992). Parental Involvement in Education:how do parents want to become involved?.Educational studies, 18(1), 11-20.

[21] Redding, S. (1992). Parent scale to measure the efficacy of strategies to enhance the curriculum of the home. In A Paper Presented at the Manual Meeting of the American Educational Research Association.

[22] Senechal, M. (2006). Testing the home literacy model: Parent involvement in kindergarten is differentially related to grade 4 reading comprehension, fluency, spelling, and reading for pleasure. Scientific Studies of Reading, 10(1), 59-87.

[23] Sheldon, S. B., \& Epstein, J. L. (2005). Involvement counts: Family and community partnerships and mathematics achievement. The Journal of Educational Research, 98(4), 196-207.

[24] Vera, E. M., Israel, M., Coyle, L., Cross, J., Knight-Lynn, L., Moallem, I., \& Goldberger, N. (2012). Exploring the educational involvement of parents of English Learners. School Community Journal, 22(2)

[25] Vural, B. (2004). Family-school partnership for student success. Istanbul, Hayat publishing.

[26] Xuesong, G. (2006). Strategies used by Chinese parents to support English language learning: Voices of 'Elite' university students. RELC Journal, 37(3), 285-298. 